\title{
REVIEW OF 170 CASES OF PERFORATED PEPTIC ULCER, 1950-1953
}

\author{
By N. F. Kirkman, M.D., F.R.C.S. \\ Senior Registrar, South Manchester Group
}

For over fifty years, perforated peptic ulcers have been treated as surgical emergencies. The perforation in the base of the ulcer has been sutured at immediate operation. Since 1946 , when Hermon Taylor reported his series of conservatively treated perforated peptic ulcers, great interest has been taken in conservative treatment, although it has not been widely adopted. The frequency of perforated peptic ulcers and the difference of opinion as to the best methods of treatment, (Hermon Taylor, 1946, I95 I, Beattie, 195 I, Chrombie, 1954), suggested that it was worthwhile reviewing the cases of perforated peptic ulcer which had been treated at Withington Hospital during the last four years, 1950-1953. It was thought that the effects of conservative or operative treatment would not be masked by changes in ancillary aids during this period, as it had not been marked by any striking advance in antibiotic therapy or anaesthetic methods; previous advances were being consolidated rather than extended in these four years.

Recent figures for the operative mortality in perforated peptic ulcer vary from I I per cent., (r948), McElhinney and Holzer, (Junr.), to 4 per cent., (1950), Avery Jones, Parsons, White. In I946, and again in $195 \mathrm{I}$, Hermon Taylor reported good results and a mortality of 9.6 per cent., using conservative treatment. Stead, (I95I), gave a Io per cent. mortality and Bullough, (1950), a 7.I per cent. mortality, using non-operative treatment. In the patients presented here, operative treatment has been favoured, although from time to time cases deemed fit for operation have been treated conservatively. These cases have formed a small non-operative series, together with a few cases where the diagnosis was at first in doubt. A second group of conservatively treated cases was formed by those cases of perforated peptic ulcer which were too ill for operation on admission. All cases in the non-operative series were proved to have ulcers at subsequent operation, or shown radiologically to have subdiaphragmatic air and a peptic ulcer on re-X-ray.
Table I shows the results of conservative treatment in 29 cases of perforated ulcer. It will be noted that 19 cases of perforated duodenal ulcers, thought fit for operation, but treated conservatively, recovered, but on the other hand no case unfit for operation was saved by conservative treatment. Cases treated conservatively were given morphia, then aspirated hourly by a Ryle's tube and no oral fluid was allowed for 24 to 36 hours, apart from moistening of lips just before each aspiration. Their fluid requirements were provided by intravenous or rectal fluid and blood transfusions if indicated. Penicillin therapy was started at once. Oral fluid was begun after 24 to 36 hours, provided that there was no rising pulse rate or pyrexia and active peristalsis were present. Doubtful cases were re-X-rayed for evidence of alteration in subdiaphragmatic air. (Hermon Taylor, I95I).

TABle I

Cases of Perforated Peptic Ulcer, Treated Conservatively

A. Duodenal ulcer perforations :

i. Cases fit for operation on admission.

\begin{tabular}{c|c|c}
\hline Recovered & Died & Total \\
\hline 19 & $0 \ldots$ & 19 \\
\hline
\end{tabular}

ii. Cases unfit for operation on admission.

\begin{tabular}{c|c|c}
\hline Recovered & Died \\
\hline 0 & $\frac{\text { Total }}{4}$ \\
\hline
\end{tabular}

B. Gastric ulcer perforations :

i. Cases fit for operation on admission: 0 .

ii. Cases unfit for operation on admission.

\begin{tabular}{c|c|c}
\hline Recovered & Died \\
\hline 0 & 6
\end{tabular}

Total-29 cases: 19 recovered, ro died. 
Table II gives the results obtained in treating I 25 cases of perforated ulcer by operation. This table confirms the usually reported greater frequency and the better prognosis of duodenal ulcer perforations. (Duodenal ulcer perforations operative mortality-2.4 per cent., gastric ulcer perforations operative mortality- 12.5 per cent.).

In all cases except one, the perforation was closed by simple suture, using 60 linen thread. In one case, an urgent partial gastrectomy, Billroth I type was performed, where a $5 \mathrm{~cm}$. perforation was found in the base of a gastric ulcer. The patient was a man aged 68 , and he unfortunately succumbed after eight days to low grade upper abdominal peritonitis.

\section{TABLE 2}

Perforated Peptic Ulcer, Treated by Operation

A. Perforated duodenal ulcers.

\begin{tabular}{ll|c|c|c}
\hline & & Recovered & Died & Total \\
\hline Males & $\ldots$ & I I 5 & 2 & 117 \\
Females & $\ldots$ & 7 & 1 & 8 \\
\hline Total & $\ldots$ & 122 & 3 & 125 \\
\hline
\end{tabular}

Per cent. mortality: 2.4 per cent.

B. Perforated gastric ulcers.

\begin{tabular}{ll|c|c|c}
\hline & & Recovered & Died & Total \\
\hline Males & $\ldots$ & 5 & 2 & 7 \\
Females & $\ldots$ & 9 & 0 & 9 \\
\hline Total & $\ldots$ & 14 & 2 & I6 \\
\hline
\end{tabular}

Per cent. mortality: 12.5 per cent.
Table III outlines the cause of death in the five patients who died after operation. Two died from further necrosis of the stomach or duodenal wall, which caused re-perforation and, consequent peritonitis. Fig. I shows the stomach removed at P.M. in one of these cases, a man aged $5 \mathrm{I}$. The sutures inserted at operation may be seen intact with the fresh perforation adjacent. The friable nature of this patient's duodenum was noted at operation, but he was considered unfit for gastrectomy then, and, in spite of ascorbic acid and blood transfusion, he re-perforated on the sixth post-operative day.

Judin, (1937), and other continental writers, pay more attention to the risk of re-perforation after suture than British authors, (Maingot, I948). Judin treats most recent peptic ulcer perforations by immediate partial gastrectomy as a routine, partly because of this risk. He claimed the impressive figure of 8.5 per cent. operative mortality for 150 perforated peptic ulcers in 1934. Whilst many think that partial gastrectomy is unnecessary as a general rule, it may be a life saving procedure in cases of perforated gastric ulcer and of gross friability of the duodenum and ulcer base, where tissue vitality is greatly impaired.

Table IV outlines the cause of death in the cases treated conservatively. The first three cases in Table IV, aged $77,79,85$ respectively were so ill on admission that recovery under any treatment was unlikely. The other cases in Table IV were in a younger age group and some of them could perhaps have been saved by operation.

It will be noted from Table I that no case of perforated gastric ulcer recovered when treated conservatively. Sometimes these cases improved temporarily for a few hours or a few days and then

TABLE 3

Causes of Death in Perforated Peptic Ulcer, Treated by Operation

\begin{tabular}{|c|c|c|c|c|c|}
\hline \multicolumn{2}{|l|}{ Age } & $\begin{array}{l}\text { Duration of } \\
\text { Perforation }\end{array}$ & $\begin{array}{l}\text { Previous } \\
\text { Symptoms }\end{array}$ & Complication & P.M. \\
\hline Male, 53 . & $\cdots$ & I $\frac{1}{2}$ hours G.U. & 20 years dyspepsia & Paralytic ileus eight days & $\begin{array}{l}\text { Re-perforation of gastric } \\
\text { ulcer, }(4 \mathrm{~cm} \text {. ulcer) }\end{array}$ \\
\hline Male, $5^{1}$ & 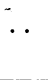 & 9 hours D.U. & six days dyspepsia & Paralytic ileus & $\begin{array}{c}\text { Re-perforation of duodenal } \\
\text { ulcer }\end{array}$ \\
\hline Female, 71 & . & 24 hours D.U. & $\begin{array}{l}\text { two weeks } \\
\text { dyspepsia }\end{array}$ & $\begin{array}{l}\text { Heart failure during in- } \\
\text { duction of anaesthesia }\end{array}$ & Myocarditis \\
\hline Male, $5^{\circ}$ & $\ldots$ & 29 hours D.U. & Nil & Paralytic ileus four days & $\begin{array}{l}\text { Peritonitis and subphrenic } \\
\text { abscess }\end{array}$ \\
\hline Male, 68 & . & 3 hours G.U. & $\begin{array}{l}\text { one month } \\
\text { dyspepsia }\end{array}$ & $\begin{array}{l}\text { Peritoneal soiling. Gross } \\
\text { G.U. Treated by gas- } \\
\text { trectomy. Died after eight } \\
\text { days }\end{array}$ & $\begin{array}{l}\text { Peritonitis } \\
\text { Myocarditis }\end{array}$ \\
\hline
\end{tabular}




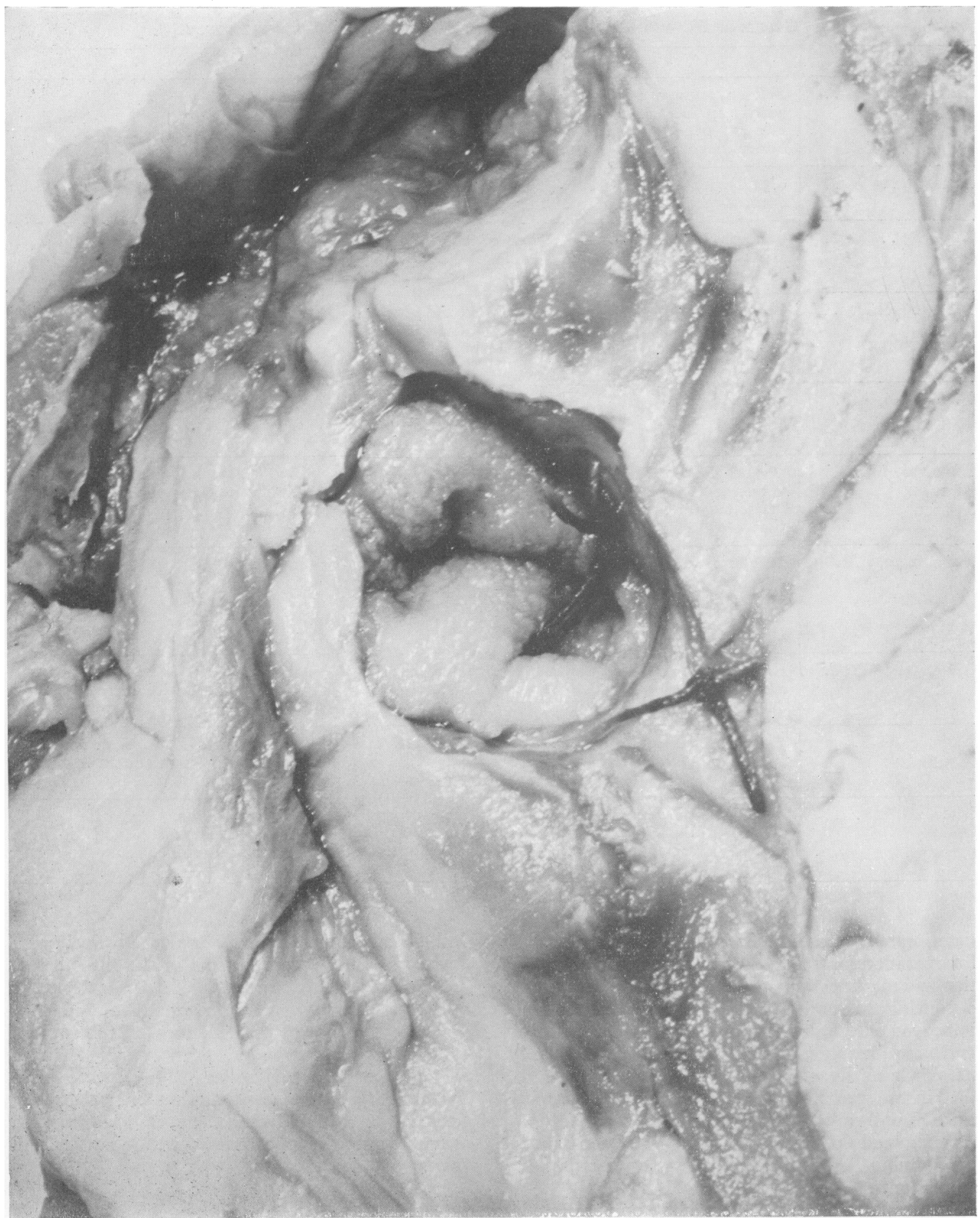

FIG. 1.-Stomach removed at post-mortem from man aged $5 \mathbf{I}$, showing re-perforation of a duodenal ulcer after suture of a previous perforation seven days before. The sutures used may be seen adjacent to the fresh perforation. 
TABLE 4

Causes of Death in Perforated Peptic Ulcer, Treated Conservatively

\begin{tabular}{|c|c|c|}
\hline Age & History and Treatment & P.M. \\
\hline Male, 77 . . & $\begin{array}{l}\text { Fell I week ago, pneumonia. } 9 \text { hours severe epi- } \\
\text { gastric pain. Saline, I.V. pencillin. Dextran. } \\
\text { Hb. } 75 \text { per cent. Died in } 3 \text { days. X-ray-air } \\
\text { under diaphragm. }\end{array}$ & - \\
\hline Male, $79 \ldots$ & $\begin{array}{l}6 / 52 \text { dyspepsia, anaemia, dyspnoea, free fluid. Ab- } \\
\text { dominal pain. Collapsed and died in } 12 \text { hours }\end{array}$ & $\begin{array}{l}\text { General peritonitis. Perforated G.U. } \\
\text { Second G.U. present }\end{array}$ \\
\hline Male, $85 \ldots$ & $\begin{array}{l}6 \text { hours severe abdominal pain. } 2 / 52 \text { dyspepsia. } \\
\text { B.P.: } 70 /- \text { on admission. Blood, I.V. penicillin. } \\
\text { Paralytic ileus. Died in } 2 \frac{1}{2} \text { days }\end{array}$ & - \\
\hline Male, 66, B.H. . & $\begin{array}{l}\text { Previous perforation I } 943 \text {, D.U. Blood and mucus } \\
\text { P.R. for months. (Ulcerative colitis 1 } 932 \text { ). I } \\
\text { month abdominal pain. Died in I } 5 \text { hours. B.P.: } \\
\text { I } 5 / 75\end{array}$ & $\begin{array}{l}\text { General peritonitis. } 2 \frac{1}{2} \text {-in. G.U. with } \\
\text { perforation. Pale colonic mucosa-not } \\
\text { ulcerated }\end{array}$ \\
\hline Female, 66, A.F. & $\begin{array}{l}5 / 52 \text { dyspepsia. B.P.: } 210 / 140.3 / 52 \text { vomiting- } \\
\text { mass (L) hypochondrium. Rapid, sudden deteriora- } \\
\text { tion. Dead in } 27 \text { hours (next morning) }\end{array}$ & $\begin{array}{l}\text { General peritonitis. } \frac{1}{4} \text {-in. perforation in } \\
\text { G.U. }\end{array}$ \\
\hline Male, 70, J.K. . . & $\begin{array}{l}2 \text { years dyspepsia, } 2 / 52 \text { severe abdominal pain and } \\
\text { vomiting - coffee grounds. Stomach held } 4 \text { pints } \\
\text { of haematemesis fluid. Treated by penicillin, aspira- } \\
\text { tion, rectal drip. Died in } 2 / 52\end{array}$ & $\begin{array}{l}3 \text { G.U.s. Two had perforated. Large } \\
\text { Rt. subphrenic abscess. General peri- } \\
\text { tonitis }\end{array}$ \\
\hline Female, 40, E.R. & $\begin{array}{l}\text { 21 hours acute abdominal pain. Pulseless on ad- } \\
\text { mission. } \\
\text { Dextran } \\
\text { Blood I.V. penicillin. } \\
\text { Died after I I hours. }\end{array}$ & $\begin{array}{l}\text { General peritonitis; } 1 \mathrm{~cm} \text {. perforation in } \\
\text { G.U. lesser curve }\end{array}$ \\
\hline Male, 55, F.T. . & $\begin{array}{l}\text { Known D.U. Perforation with haematemesis on } \\
\text { admission. Blood, I.V. penicillin. Died in } 2 \frac{1}{2} \\
\text { days }\end{array}$ & $\begin{array}{l}\text { General peritonitis. Large perforated } \\
\text { D.U. with blood vessel in floor of ulcer }\end{array}$ \\
\hline Male, 49, A.B. & $\begin{array}{l}3 \text { hours severe pain, } 5 \text { years asthma. Aspiration. } \\
\text { Penicillin. Died in } 4 \frac{1}{2} \text { hours. }\end{array}$ & $\begin{array}{l}\frac{1}{2} \text {-in. perforation of D.U. Free peritoneal } \\
\text { luid } \frac{\text { no pus. Heart and liver normal. }}{\text { ? shock }}\end{array}$ \\
\hline Male, 48, L.P. & $\begin{array}{l}\text { Polycythaemic vera, enlarged spleen. } 3 / 52 \text { dyspep- } \\
\text { sia, } 4 \text { hours actute epigastric pain. Saline/glucose } \\
\text { I.V. Aspiration. Pencillin. Multiple deep throm- } \\
\text { boses. Died in } 30 \text { hours }\end{array}$ & $\begin{array}{l}\text { General peritonitis. Perforated D.U. } \\
\text { Grossly enlarged spleen with infarcts. } \\
\text { Ante-mortem thrombus in aorta }\end{array}$ \\
\hline
\end{tabular}

deteriorated. Case F.T., male, aged 55, was fit for operation for 6 to 12 hours after initial resuscitation and might perhaps have been saved if operated on during this period. Case J.K., male, aged 70, improved temporarily on intravenous fluid therapy and was probably fit for operation for two days, but he slowly declined on conservative treatment and died in two weeks. At P.M. two large perforations were found in two gastric ulcers. Case A.F., female, aged 66 , could probably have been saved by draining her perigastric abscess on the day of admission.

Table $\mathrm{V}$ compares the effect of age on perforated ulcers, (A) treated by operation, with those (B) treated conservatively. The expected influence of age is shown in both series. Age appears to have influenced the non-operative group adversely; for instance out of seven patients in the fifth decade treated expectantly, three died. In 32 similar patients treated by operation none died.

Table VI shows the incidence of the various types of perforated peptic ulcers which occurred in 19 women in this series. There were more perforated gastric ulcers than duodenal ulcer perforations and the average age of perforation in women is 54.5 years compared with 48.3 years in men.

\section{Discussion}

Although the number of cases treated conservatively in this series is not large, it is sufficient for some inferences to be drawn when the figures are 
TABLE 5

A. Age Incidence and Mortality in Perforated Peptic Ulcer, Treated by Operation

\begin{tabular}{c|c|c|c}
\hline Age Group & Recovered & Died & Total \\
\hline $15-20$ & 3 & 0 & 3 \\
$21-30$ & 17 & 0 & 17 \\
$31-40$ & 28 & 0 & 28 \\
$41-50$ & 32 & 0 & 32 \\
$51-60$ & 23 & 3 & 26 \\
$61-70$ & 23 & 1 & 24 \\
$71-80$ & 9 & I & I0 \\
$80+$ & 1 & 0 & I \\
\hline & I36 & 5 & I4I \\
\hline
\end{tabular}

B. Age Incidence and Mortality in Perforated Peptic Ulcer, Treated Conservatively

\begin{tabular}{c|c|c|c}
\hline Age Group & Recovered & Died & Total \\
\cline { 2 - 3 } $2 \mathrm{I}-30$ & 4 & 0 & 4 \\
$3 \mathrm{I}-40$ & 4 & 0 & 4 \\
$4 \mathrm{I}-50$ & 4 & 3 & 7 \\
5I-60 & 5 & $\mathrm{I}$ & 6 \\
$6 \mathrm{I}-70$ & 0 & 2 & 2 \\
$7 \mathrm{I}-80$ & 2 & 3 & 5 \\
$8 \mathrm{I}+$ & 0 & $\mathrm{I}$ & $\mathrm{I}$ \\
\hline & $\mathrm{I9}$ & I0 & 29 \\
\hline
\end{tabular}

TABle 6

Perforations of Peptic Ulcers in Women

Perforated gastric ulcers: II, average age 55 years. Perforated duodenal ulcers: 8 , average age 54 years.

\begin{tabular}{l|c|c|c|c}
\hline \multicolumn{1}{c|}{ Treatment } & \multicolumn{2}{|c|}{ Gastric Ulcers } & \multicolumn{2}{c}{ Duodenal Ulcers } \\
\hline Opecovered & Died & Recovered & Died \\
\hline Conservative & 9 & 0 & 6 & $\mathrm{I}$ \\
\hline
\end{tabular}

compared with those of the group treated by operation.

I. The prognosis of a perforated gastric ulcer treated conservatively is bad; when treated operatively the prognosis is better, (12.5 per cent. operative mortality), but not as good as that of a perforated duodenal ulcer treated by operation.

From observation at operation, it was frequently noted that perforated gastric ulcers, expecially if anteriorly placed, showed no signs of closing or being occluded by adherence to adjacent viscera. Beattie, (I95I), stresses this point in discussing conservative treatment of perforations.

2. As age increases, the frequency of perforations of other abdominal viscera increases, i.e., perforations of the biliary tract, the colon and the small bowel. These often present a clinical picture closely simulating peptic ulcer perforations and delay in diagnosis and operative treatment in these cases may be fatal (Chrombie, I954).

Doll, (1950), showed that in a series of 86 perforated gastric ulcers in men, seven were carcino- matous; operation at the time of perforation alone offers such cases the chance of a successful issue and operation is often the best means of palliation. Doll maintains that contrary to popular belief, perforation of a gastric carcinoma does not necessarily indicate inevitable peritoneal metastases. The late Gray Turner, (1946), pertinently asked how many patients will lose their lives through having conservative treatment for a wrongly diagnosed peptic ulcer perforation. It is the older patients with the greater potential variety of upper abdominal lesions who will provide most of the mistakes of conservative treatment. On the other hand, it must be remembered that 19 cases of proved duodenal ulcer in the present series, in otherwise fit patients, were treated conservatively with no mortality, their average age being 44.3 years.

From the details of this series and the points outlined above, it seems fair to suggest:

I. That cases of probable perforated gastric ulcers should be rendered fit for operation as soon as possible and treated by operation. This means all cases over 50 years of age, expecially women, presenting with signs of sudden severe peritoneal irritation.

2. That the value of expectant treatment is chiefly in dealing with young patients who have also some additional chronic disease such as diabetes, chronic bronchitis, etc. In young patients the possibility of a perforated appendicitis must be seriously considered.

3. Although simple suture of the perforation is all that is required in the great majority of cases, there are a few, which might be saved by urgent gastrectomy, where the ulcer base is extremely friable and likely to perforate again, or where the ulcer is malignant, (three in this series).

\section{Summary}

I 70 cases of perforated peptic ulcer are presented. The majority, I4I, were treated by operation, 29 were treated conservatively.

Details of age incidence and mortality, and the results of treatment, are given.

The advantages and drawbacks of conservative and operative treatment are discussed.

I am grateful to Mr. H. T. Cox, Mr. T. Moore, Mr. A. Nicholson, for help in treating some of these cases, to Dr. Stent for innumerable pathological investigations and advice, to the Sisters and Nurses of the surgical side at Withington Hospital for their efficient and kindly care of these patients, and to the Surgical Registrars who operated on most of these cases, especially Messrs. H. F. Smith, F.R.C.S., L. R. McLaren, F.R.C.S., and J. Jalundhwalla, F.R.C.S.

Bibliography on next page. 


\section{OBSTETRICS \& GYNAECOLOGY}

(Postgraduate Medical Journal, July, 1954)

Price : 3s. 8d., post free

\section{INTRODUCTORY}

Charles D. Read, F.R.C.S., F.R.C.O.G.

RESPIRATORY HAZARDS IN THE PREMATURE INFANT

Albert E. Claireaux, M.D., M.R.C.P.

\section{POSTMATURITY}

S. G. Clayton, M.D., M.S., F.R.C.O.G.

THE RELATIVE MERITS OF THE VARIOUS BIOLOGICAL TESTS FOR PREGNANCY

H. P. Ferreira, M.D.

\section{PELVIC THROMBOSIS}

J. Stallworthy, F.R.C.S., F.R.C.O.G.

THE EARLY DIAGNOSIS OF GENITAL CANCER BY CYTOLOGY

Erica Waechtel, M.D.

\section{THE MENOPAUSE}

G. I. M. Swyer, D.M., M.R.C.P.

THE PLACE OF ULTRA-RADICAL SURGERY IN ADVANCED MALIGNANT DISEASE IN THE PELVIS

J. B. Blaikley, F.R.C.S., F.R.C.O.G.

Published by

THE FELLOWSHIP OF POSTGRADUATE MEDICINE

60, Portland Place, London, W.1

\section{NOTICE OF SPECIAL INTEREST TO SUBSCRIBERS:}

"WHY NOT HAVE YOUR COPIES OF THIS JOURNAL BOUND INTO YEARLY VOLUMES?"

Arrangements have now been made to have the twelve monthly issues fully bound in dark green pin head cloth, lettered in gilt on spine with name of Journal, Volume Number and year, complete with index at front, 17s. 6d. per Volume, post free. A limited number of out of print journals are available to bind into volumes and make your library complete. Price on application giving details of issues required to complete back volumes.

THE FELLOWSHIP OF POSTGRADUATE MEDICINE 60 PORTLAND PLACE, LONDON, W.I
WHY NOT

HAVE YOUR

JOURNALS

BOUND?

Bibliography continued from previous page.-N. F. Kirkman, M.D., F.R.C.S.

\section{BIBLIOGRAPHY}

BEATTIE, A. D. (1951), Brit. med. F., i, 992.

BULLOUGH, A. S. (1950), Communication, M/Cr. Surg. Soc.

CHROMBIE, T. G. (1954), Brit. med. F., i, 374.

DOLL, R. (1950), Ibid., i, 215.

JONES, A. F., PARSONS, P. J., and WHITE, B., Ibid., i, 211.

MCELHINNEY, W. T., and HOLZER, C. E. Jun. (1948), Surg.

Gynec. Obstet., 87, 85 .
STEAD, J. R. ST. G. (195I), Lancet, i, 12. TAYLOR, HERMON (1946), Lancet, ii, 44r. TAYLOR, HERMON (195 I), Ibid., i, 7 . TURNER, G. GRAY (1946), See Taylor, Hermon (1946). JUDIN, H. (1937), Surg. Gynec. Obstet., 64, 63. MAINGOT, RODNEY (I948), 'Abdominal Operations,' second edition, Appleton, New York. 